\title{
A STUDY OF THE COMPOSITION OF THE ALKALOIDS
}

OF Corydalis persica

N. N. Margvelashvili and D. A. Pakali

UDC 547.944/945

We have investigated Corydalis persica Cham et Schlecht, family Papaveraceae, the alkaloid composition of which has not been studied previously. From the tubers collected in the flowering phase (June 1, 1972) in the Bichinakskii Pass we isolated the combined alkaloids (1.63\%) by the dichloroethane method.

By column chromatography on alumina (activity grade II) with elution by diethyl ether we obtained a white crystalline optically inactive substance with the composition $\mathrm{C}_{20} \mathrm{H}_{15} \mathrm{O}_{5} \mathrm{~N}, \mathrm{mp} 266-267^{\circ} \mathrm{C}$ (ether) which was identified as sanguinarine [1].

Elution with diethyl ether-chloroform (97:3) gave chelerythrine, $\mathrm{C}_{21} \mathrm{H}_{19} \mathrm{O}_{5} \mathrm{~N}, \mathrm{mp} 208^{\circ} \mathrm{C}$ (ether) [1]. Elution with diethyl ether-chloroform (95:5) gave a substance with the composition $\mathrm{C}_{20} \mathrm{H}_{19} \mathrm{O}_{5} \mathrm{~N}, \mathrm{mp}_{204-}$ $205^{\circ} \mathrm{C}$, which was identical with an authentic sample of protopine [2].

\section{LITERATURE CITED}

1. T. A. Henry, The Plant Alkaloids, 4th ed., J. A. Churchill, London (1949).

2. A. P. Orekhov, Alkaloid Chemistry [in Russian], Moscow (1955), p. 493.

All-Union Scientific-Research Institute of Medicinal Plants. Translated from Khimiya Prirodnykh Soedinenii, No. 1, p. 133, January-February, 1973. Original article submitted July $27,1972$.

- 1975 Consultants Bureau, a division of Plenum Publishing Corporation, 227 West 17th Street, New York, N. Y. 10011. No part of this publication may be reproduced, stored in a retrieval system, or transmitted, in any form or by any means, electronic, mechanical, photocopying, microfilming, recording or otherwise, without written permission of the publisher. A copy of this article is available from the publisher for $\$ 15.00$. 